\title{
GMR
}

\section{Karyotype evolution in the genus Jacaranda Juss. (Jacarandeae, Bignoniaceae): chromosome numbers and heterochromatin}

\author{
J.M.P. Cordeiro, S.A.A. Lima, S.N. Paz, A.M.S. Santos and L.P. Felix \\ Departamento de Biologia, Centro de Ciências Agrárias, \\ Universidade Federal da Paraíba, Campus II, Areia, PB, Brasil \\ Corresponding author: J.M. P. Cordeiro \\ E-mail: joelmpcordeiro@yahoo.com.br
}

Genet. Mol. Res. 15 (4): gmr15048973

Received July 14, 2016

Accepted August 19, 2016

Published October 17, 2016

DOI http://dx.doi.org/10.4238/gmr15048973

Copyright (C) 2016 The Authors. This is an open-access article distributed under the terms of the Creative Commons Attribution ShareAlike (CC BY-SA) 4.0 License.

\begin{abstract}
Most taxa in the Bignoniaceae have $2 n=40$, but the basal clade Jacarandeae has $2 n=36$, suggesting that $x=18$ is the ancestral basic number for the family. Variations in heterochromatin band patterns in genera that are numerically stable, such as Jacaranda, could facilitate our understanding of the chromosomal and karyotypic evolution of the family. We characterized heterochromatin distributions in six Jacaranda species using chromomycin A3 (CMA) and 4'6-diamidino-2-phenylindole (DAPI). All of them had $2 n=36$, including first counts for Jacaranda bracteata Bureau \& K. Schum., Jacaranda irwinii A.H. Gentry, Jacaranda jasminoides (Thunb.) Sandwith, and Jacaranda rugosa A.H. Gentry. Their karyotypes had four to eight terminal $\mathrm{CMA}^{+} / \mathrm{DAPI}^{-}$bands per monoploid set. In the section Monolobos, Jacaranda brasiliana (Lam.) Pers. had eight terminal bands and Jacaranda mimosifolia D. Don had four; in the section Dilobos, J. bracteata had six bands per monoploid set, with the
\end{abstract}


other species having five. While three species in the section Dilobos had the same number of terminal bands, $J$. irwinii had two additional pericentromeric bands and a proximal heterozygotic band, and $J$. bracteata had two distended CMA bands. The consistent records of $2 n$ $=36$ in Jacaranda may represent a plesiomorphic condition for the Bignoniaceae; therefore, the family originated from an ancestor with $x=18$. However, $2 n=36$ may represent a derived condition, and the family could have had an ancestral basic number of $x=20$ that is still conserved in most representatives of the family.

Key words: Jacaranda; Cytotaxonomy; CMA/DAPI; Terminal heterochromatin; Karyotypic variation

\section{INTRODUCTION}

The tribe Jacarandeae comprises 55 species of trees and shrubs belonging to the genera Jacaranda and Digomphia Benth., and has a strictly Neotropical distribution (Olmstead et al., 2009). Jacaranda has the greatest number of species in the tribe, and is one of the largest genera of the family Bignoniaceae, with 49 species (Gentry and Morawetz, 1992; Lohmann and Ulloa, 2016). The taxon is characterized by bi-pinnate or pinnate leaves, flowers with corollas blue or blue-purple to magenta, staminode elongate, exceeding the stamens, a calyx short and broadly campanulate to cupular, and fruit oblong, flattened, perpendicular to the septum (Morawetz, 1982; Gentry and Morawetz, 1992).

The genus is subdivided into two sections: Monolobos DC. and Dilobos Endl. The section Monolobos has 1-thecate anthers, and comprises 18 species that are found in the Antilles, Central America, and the western part of South America; the section Dilobos, which is considered the most primitive, has 2-thecate anthers and comprises 31 species that are mainly found in Brazil (Morawetz, 1982; Gentry and Morawetz, 1992; Dos Santos and Miller, 1997). Molecular phylogenetic analyses have indicated that the tribe Jacarandeae is the most basal in the family, and is a sister group to the other Bignoniaceae (Spangler and Olmstead, 1999; Olmstead et al., 2009). These analyses, however, only included four species, with two from the section Monolobos and two from the section Dilobos, and their relationships are unresolved (Olmstead et al., 2009).

The Bignoniaceae exhibits notable numerical karyotypic stability, with most species having $2 n=40$ (Goldblatt and Gentry, 1979; Piazzano, 1998; Piazzano et al., 2015); the Jacarandeae, however, have $2 n=36$ in all of the 16 species of Jacaranda the karyotypes of which have been analyzed (Goldblatt and Gentry, 1979; Morawetz, 1982; Costa, 2006; Sampaio, 2010). There are no known chromosome records for the genus Digomphia.

Analyses that involve staining with the fluorochromes chromomycin A3 (CMA) and 4'6-diamidino-2-phenylindole (DAPI) have proven to be very useful in taxonomic studies, and in examinations of karyotypic evolution in plant groups with stable chromosome numbers. Numerically stable species of Citrus L. (Guerra, 1993; Carvalho et al., 2005), Spondias L. (Almeida et al., 2007), and Acianthera Scheidw. (Oliveira et al., 2015), for example, have been karyotypically characterized based on their patterns of CMA/DAPI bands. Although analyses

of CMA/DAPI banding patterns have been important in defining species and investigating karyotypic evolution, this technique has not been widely used in the Bignoniaceae.

Genetics and Molecular Research 15 (4): gmr15048973 
A number of Jacaranda species have restricted distributions (Gentry and Morawetz, 1992), or are considered rare or threatened with extinction (Lohmann et al., 2013). Species such as Jacaranda mimosifolia D. Don are widely cultivated as ornamentals (Gentry, 1992). However, most species of the genus are difficult to cultivate, and produce recalcitrant seeds that can only be stored for short periods of time before losing their germinative ability (Sangalli et al., 2012), often making it difficult to obtain material appropriate for cytological analyses of its species.

Approximately $30 \%$ of Jacaranda species have been karyotypically analyzed, with all of them having $2 n=36$ and symmetrical karyotypes, making them difficult to characterize using conventional staining techniques (Goldblatt and Gentry, 1979; Morawetz, 1982; ForniMartins and Martins, 2000; Costa, 2006; Sampaio, 2010). The use of different staining techniques in Jacaranda could differentiate the chromosomes of its species, including the karyotypic characterization of the subsections Monolobos and Dilobos, and morphologically similar species. Therefore, this study aimed to characterize the karyotypes of six species of Jacaranda belonging to the sections Monolobos (two species) and Dilobos (four species) using CMA and DAPI.

\section{MATERIAL AND METHODS}

Almost all of the plant material used was collected in the field (Caatinga and Cerrado vegetation), with only one cultivated species taken from an urban garden (J. mimosifolia D. Don). Specimens of all of the material analyzed were deposited in the Prof. Jayme Coelho de Moraes Herbarium at Universidade Federal da Paraíba, Brazil.

Cytogenetic analyses were performed on root tips treated with $0.002 \mathrm{M}$ 8-hydroxyquinoline at $4^{\circ} \mathrm{C}$ for $24 \mathrm{~h}$, fixed in Carnoy's solution (absolute ethanol:glacial acetic acid; $3: 1, \mathrm{v} / \mathrm{v}$ ) for $3 \mathrm{~h}$, and subsequently stored at $-20^{\circ} \mathrm{C}$. To prepare the slides, the root tips were digested in an enzymatic solution ( $2 \%$ cellulase $+20 \%$ pectinase) and maintained under humid conditions at $37^{\circ} \mathrm{C}$ for $1 \mathrm{~h}$. The material was then squashed in $45 \%$ acetic acid and the slides were frozen in liquid nitrogen to remove their cover slips. The slides were then stained with a solution of DAPI $(2 \mu \mathrm{g} / \mathrm{mL})$ :glycerol $(1: 1, \mathrm{v} / \mathrm{v})$. The best slides were selected and cleared in ethanol:acidic acid (3:1) for $30 \mathrm{~min}$, and subsequently were maintained in absolute alcohol for $2 \mathrm{~h}$. The slides were cured for three days and then stained for $1 \mathrm{~h}$ with $10 \mu \mathrm{L}$ CMA $(0.1 \mathrm{mg} / \mathrm{mL})$, and then with $10 \mu \mathrm{L}$ DAPI $(2 \mu \mathrm{g} / \mathrm{mL})$ for $30 \mathrm{~min}$. They were then mounted in glycerol:McIlvaine buffer, $\mathrm{pH} 7.0(1: 1, \mathrm{v} / \mathrm{v})$, and stored for three days in the dark to stabilize the fluorochromes (Guerra and Souza, 2002).

At least three slides were analyzed for each species, with the best metaphases being photographed using an AxioCam MRc 5 video camera (Carl Zeiss Vision GmbH, MünchenHallbergmoos, Germany) coupled to a Zeiss Scope.A1 microscope (Carl Zeiss Microlmaging GmbH, Göttingen, Germany) using the AxioVision v.4.8 software. Chromosomal measurements were made using the ImageTool v.3.0 software (http://compdent.uthscsa.edu/dig/itdesc.html). The images were edited and the karyograms mounted using Adobe Photoshop CS3 v.10.0.

\section{RESULTS}

All of the species exhibited $2 n=36$, and had symmetrical karyotypes with mediumsized metacentric and submetacentric chromosomes that varied in median length from 1.83

Genetics and Molecular Research 15 (4): gmr15048973 
$\pm 0.34 \mu \mathrm{m}$ in J. mimosifolia to $2.82 \pm 0.54 \mu \mathrm{m}$ in Jacaranda rugosa A.H. Gentry (Table 1). Previously reported chromosome counts and the new counts recorded here for Jacaranda represent a total of 20 species analyzed ( $41 \%$ of the genus), and all of them have $x=18$ (Table 2 ).

Table 1. Characteristics of the Jacaranda species analyzed.

\begin{tabular}{l|l|l|l|l}
\hline Section/species & Habit & Biome & $2 n$ & Median size \\
\hline Monolobos & & & & \\
\hline Jacaranda brasiliana (Lam.) Pers. & Tree & Cerrado & 36 & $2.64 \mu \mathrm{m}$ \\
\hline J. mimosifolia D. Don & Tree & Cultivate & 36 & $1.83 \mu \mathrm{m}$ \\
\hline Dilobos & & & & \\
\hline J. bracteata Bureau \& K. Schum.* & Shrub & Cerrado & 36 & $2.18 \mu \mathrm{m}$ \\
\hline J. irwinii A.H. Gentry* & Shrub & Cerrado & 36 & $2.10 \mu \mathrm{m}$ \\
\hline J.jasminoides (Thunb.) Sandwith* & Shrub & Caatinga & 36 & $2.17 \mu \mathrm{m}$ \\
\hline J. rugosa A.H. Gentry* & Shrub & Caatinga & 36 & $2.82 \mu \mathrm{m}$ \\
\hline
\end{tabular}

*First chromosome count for the species.

Table 2. Chromosome numbers recorded for Jacaranda species and their respective bibliographic references.

\begin{tabular}{l|l|l}
\hline Species & $2 n$ & Source \\
\hline J. acutifolia Bonpl. & 36 & Sampaio (2010) \\
\hline J. bracteata Bureau \& K. Schum. & 36 & Present study \\
\hline J. brasiliana (Lam.) Pers. & 36 & Morawetz (1982); Costa (2006); present study \\
\hline J. caerulea (L.) J. St.-Hil. & 36 & Morawetz (1982) \\
\hline J. caroba (Vell.) DC. & 36 & Forni-Martins and Martins (2000); Sampaio (2010) \\
\hline J. cuspidifolia Mart. & 36 & Costa (2006) \\
\hline J. decurrens Cham. & 36 & Sampaio (2010) \\
\hline J. hesperia Dugand & 36 & Goldblatt and Gentry (1979); Morawetz (1982) \\
\hline J. irwinii A.H. Gentry & 36 & Present study \\
\hline J. jasminoides (Thunb.) Sandwith & 36 & Present study \\
\hline J. macrantha Cham. & 36 & Morawetz (1982) \\
\hline J. micrantha Cham. & 36 & Morawetz (1982) \\
\hline J. mimosifolia D. Don & 36 & Goldblatt and Gentry (1979); Piazzano (1998); Costa (2006); present study \\
\hline J. paucifoliata Mart. ex DC. & 36 & Sampaio (2010) \\
\hline J. puberula Cham. & 36 & Morawetz (1982) \\
\hline J. pulcherrima Morawetz & 36 & Morawetz (1982) \\
\hline J. rugosa A.H. Gentry & 36 & Present study \\
\hline J. rufa Silva Manso & 36 & Morawetz (1982); Sampaio (2010) \\
\hline J. subalpina Morawetz & 36 & Morawetz (1982) \\
\hline J. ulei Bureau \& K. Schum. & 36 & Sampaio (2010) \\
\hline
\end{tabular}

The heterochromatic banding patterns observed in the Jacaranda species studied here were characterized by the presence of four to eight terminal bands rich in CG sequences $\left(\mathrm{CMA}^{+} / \mathrm{DAPI}^{-}\right)$per monoploid set. In the section Monolobos, Jacaranda brasiliana (Lam.) Pers. had eight terminal $\mathrm{CMA}^{+} / \mathrm{DAPI}^{-}$bands per monoploid set (Figure 1A, B), while $J$. mimosifolia had four, two of them being distended (Figure 1C, D). In the section Dilobos, Jacaranda bracteata Bureau \& K. Schum. had six terminal CMA ${ }^{+} / \mathrm{DAPI}^{-}$bands per monoploid set (Figure 2A, B), while Jacaranda irwinii A.H. Gentry (Figure 2C, D), J. jasminoides (Thunb.) Sandwith (Figure 2E, F), and J. rugosa (Figure 2G, H) had five, the latter with two chromosome pairs showing distended $\mathrm{CMA}^{+}$bands, which probably corresponded to nucleolar organizer regions (NORs). Of the species analyzed, only J. irwinii had a proximal heterozygotic CMA band at one of the homologs of chromosome pair 1 and two proximal bands on pair 6 (Figure 2D). 

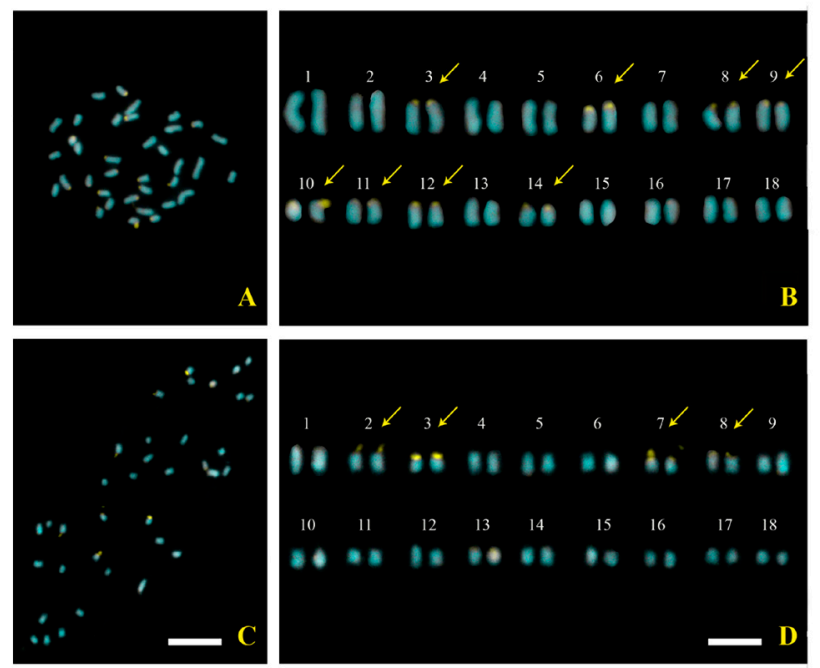

Figure 1. Mitotic metaphases and karyograms of Jacaranda species from the section Monolobos. A. B. Jacaranda brasiliana $(2 n=36)$; C. D. Jacaranda mimosifolia $(2 n=36)$. Scale bar in $\mathbf{C}$ corresponds to $10 \mu \mathrm{m}$; scale bar in $\mathbf{D}$ corresponds to $5 \mu \mathrm{m}$. Arrows indicate homologous chromosomes with terminal $\mathrm{CMA}^{+}$bands.
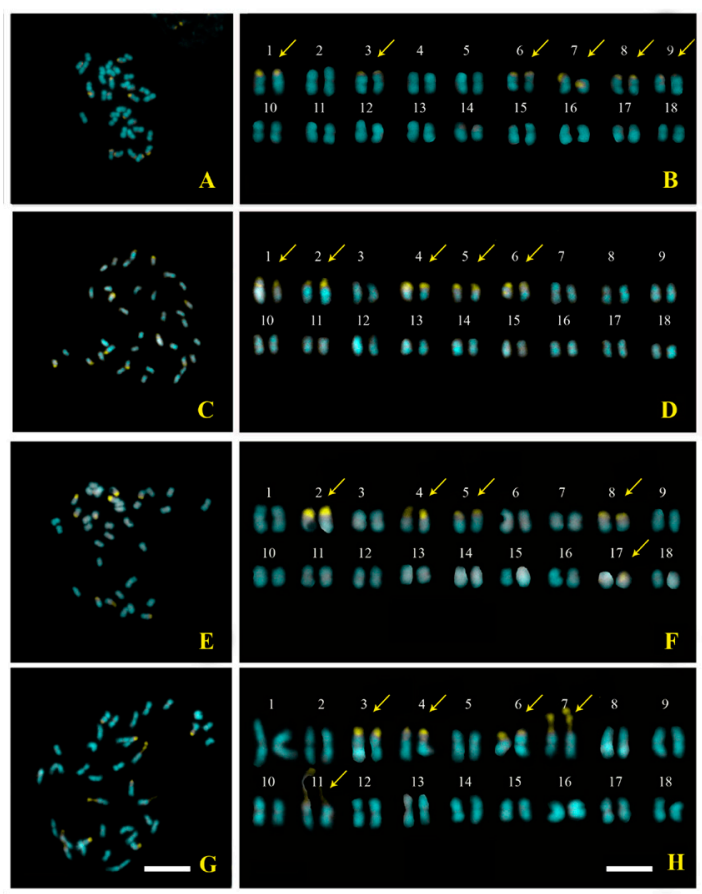

Figure 2. Mitotic metaphases and karyograms of Jacaranda species from the section Dilobos. A. B. Jacaranda bracteata $(2 n=36)$; C. D. Jacaranda irwinii $(2 n=36)$; E. F. Jacaranda jasminoides $(2 n=36)$; G. H. Jacaranda rugosa $(2 n=36)$. Scale bar in $\mathbf{G}$ corresponds to $10 \mu \mathrm{m}$; scale bar in $\mathbf{H}$ corresponds to $5 \mu \mathrm{m}$. Arrows indicate homologous chromosomes with terminal $\mathrm{CMA}^{+}$bands.

Genetics and Molecular Research 15 (4): gmr15048973 


\section{DISCUSSION}

The present study confirmed previous counts of $2 n=36$ for $J$. mimosifolia and $J$. brasiliana (Goldblatt and Gentry, 1979; Morawetz, 1982; Piazzano, 1998; Costa, 2006), with the other counts being new for the genus. The numerical stability observed in Jacaranda has been reported in other genera of Bignoniaceae, particularly in the tribes Catalpeae, Bignonieae, and Crescentieae, and the Tabebuia alliance clade, although in this, and in most of the other genera in Bignoniaceae, $2 n=40$ predominates (Goldblatt and Gentry, 1979; Piazzano, 1998; Piazzano et al., 2015). Difficulties have been encountered in identifying some species of Jacaranda due to morphological similarities in terms of their habits, leaf structures, the colors and morphologies of their flowers, and similarities in the shapes of their fruits (Gentry and Morawetz, 1992; Silva-Castro et al., 2007). Although chromosome numbers have been widely and traditionally used in plant cytotaxonomy (Guerra, 2008), this parameter is not informative in genera with similar chromosome numbers and morphologies, as Jacaranda. In these cases, the use of differential staining techniques, such as CMA/DAPI banding, has proven to be viable alternatives for cytotaxonomic studies, particularly when characterizing closely related species (Guerra, 2000).

Jacaranda had variable numbers of terminal $\mathrm{CMA}^{+} / \mathrm{DAPI}^{-}$bands, which allowed individual karyotypic characterizations of each of the six species analyzed here. The numbers of bands were variable among the arborescent species (section Monolobos), with four and eight pairs of bands in J. mimosifolia and J. brasiliana, respectively. The shrub species (section Dilobos) exhibited greater karyotypic stability, with three of the four species analyzed having five pairs of terminal $\mathrm{CMA}^{+}$bands, with only $J$. bracteata having six bands. Of the species with five pairs of terminal $\mathrm{CMA}^{+}$bands, $J$. rugosa differed by having two pairs with notably distended NORs, while $J$. irwinii had proximal bands on two chromosome pairs.

Although variations in the numbers and sizes of the CMA/DAPI bands were observed among the Jacaranda species analyzed here, these differences may not be sufficient to karyotypically distinguish between the sections Monolobos and Dilobos, because other species of the genus will probably have terminal $\mathrm{CMA}^{+}$bands with sizes and numbers similar to those reported here, independent of the section to which they have been assigned. Such similarities between Jacaranda sections have been observed in phylogenetic analyses of base-pair sequences in the $n d h \mathrm{~F}, r b c \mathrm{~L}$, and $t r n \mathrm{~L}-\mathrm{F}$ regions (Olmstead et al., 2009). Although 1-2-thecate anthers have been of practical use in separating these two sections (Gentry and Morawetz, 1992), this morphological characteristic does not appear to constitute a synapomorphy. It will therefore be necessary to undertake wider samplings of the species of both sections in order to support (or not) the current infrageneric classification of Jacaranda.

The patterns of CMA/DAPI bands observed in Jacaranda species diverge from those most frequently reported for angiosperms, with a single band corresponding to a heterochromatic NOR accompanied by pericentromeric bands and variable numbers of terminal bands (reviewed by Guerra, 2000). Although the numbers and sizes of the bands in Jacaranda are variable, they demonstrate equilocal distributions in the terminal regions of the chromosomes of most species, suggesting a consistent mechanism of chromosomal evolution. The presence of multiple copies of repeated DNA sequences in the terminal chromosome regions may have been caused in this case by pairing non-homologous chromosomes, thus amplifying recombination frequencies, and, consequently, the number of terminal heterochromatin loci in the genome (Bennetzen and Wang, 2013).

Genetics and Molecular Research 15 (4): gmr15048973 
Regarding karyotypic numerical stability, two hypotheses may explain the constant occurrence of $2 n=36$ in Jacaranda. The first hypothesis is based on the molecular phylogeny proposed by Olmstead et al. (2009), in which Jacarandeae appears as the basal group of the family Bignoniaceae, which would support $x=18$ as the probable ancestral basic number of the family. The second hypothesis, which is supported by most of the authors that have discussed the karyotypic evolution of the Bignoniaceae (Goldblatt and Gentry, 1979; Piazzano, 1998; Piazzano et al., 2015), proposes $x=20$ as the basic chromosome number of the family, based on the consistent appearance of $2 n=40$ in most of its genera (as well as closely related families, such as the Paulowniaceae and Schlegeliaceae). According to the latter hypothesis, the chromosome numbers reported for Jacaranda would be derived from $2 n$ $=40$, which would have experienced chromosomal rearrangements of the centric fission type, with stabilization at $2 n=36$. However, whether by chromosomal rearrangement or because of the primitive characteristics of the Bignoniaceae, the establishment of a karyotype with $2 n=36$ in Jacaranda was related to the evolution of one of the most diverse groups in the Bignoniaceae, with approximately 50 species that are adapted to a wide variety of Neotropical habitats (Gentry and Morawetz, 1992).

\section{Conflicts of interest}

The authors declare no conflict of interest.

\section{ACKNOWLEDGMENTS}

We thank to Conselho Nacional de Desenvolvimento Científico e Tecnológico (CNPq) and Coordenação de Aperfeiçoamento de Pessoal de Nível Superior (CAPES) for financial support and Instituto Nacional do Semiárido for technical support.

\section{REFERENCES}

Almeida CCS, Carvalho PCL and Guerra M (2007). Karyotype differentiation among Spondias species and the putative hybrid umbu-cajá (Anacardiaceae). Bot. J. Linn. Soc. 155: 541-547. http://dx.doi.org/10.1111/j.10958339.2007.00721.x

Bennetzen JL and Wang H (2013). The contributions of transposable elements to the structure, function, and evolution of plant genomes. Annu. Rev. Plant Biol. 65: 19.1-19.26.

Carvalho R, Soares Filho WS, Brasileiro-Vidal AC and Guerra M (2005). The relationships among lemons, limes and citron: a chromosomal comparison. Cytogenet. Genome Res. 109: 276-282. http://dx.doi.org/10.1159/000082410

Costa RS (2006). Caracterização morfológica, citogenética e molecular de espécies de Jacaranda (Bignoniaceae) cultivadas em Jaboticabal - SP. Doctoral thesis, Faculdade de Ciências Agrárias e Veterinárias, UNESP, Jaboticabal.

Dos Santos G and Miller RB (1997). Wood anatomy of Jacaranda (Bignoniaceae): systematic relationships in sections Monolobos and Dilobos as suggested by twig and stem wood rays. IAWA J. 18: 369-383. http://dx.doi. org/10.1163/22941932-90001502

Forni-Martins ER and Martins FR (2000). Chromosome studies on Brazilian cerrado plants. Genet. Mol. Biol. 23: $947-$ 955. http://dx.doi.org/10.1590/S1415-47572000000400040

Gentry AH (1992). A synopsis of Bignoniaceae: ethnobotany and economy botany. Ann. Mol. Bot. Gard. 79: 53-64. http:// dx.doi.org/10.2307/2399809

Gentry AH and Morawetz W (1992). Jacaranda. In: Bignoniaceae Part II (Tribe Tecomeae) (Flora Neotropica Monograph 25(II)) (Gentry AH, ed.). The New York Botanical Garden Press, New York.

Goldblatt P and Gentry AH (1979). Cytology of Bignoniaceae. Bot. Not. 132: 475-482.

Guerra M (1993). Cytogenetics of Rutaceae. V. High chromosomal variability in Citrus species revealed by CMA/DAPI

Genetics and Molecular Research 15 (4): gmr15048973 
staining. Heredity 71: 234-241. http://dx.doi.org/10.1038/hdy.1993.131

Guerra M (2000). Patterns of heterochromatin distribution in plant chromosomes. Genet. Mol. Biol. 23: 1029-1041. http:// dx.doi.org/10.1590/S1415-47572000000400049

Guerra M (2008). Chromosome numbers in plant cytotaxonomy: concepts and implications. Cytogenet. Genome Res. 120 : 339-350. http://dx.doi.org/10.1159/000121083

Guerra M and Souza MJ (2002). Como observar cromossomos: Um guia de técnicas em citogenética vegetal, animal e humana. 1st edn. FUNPEC, Ribeirão Preto.

Lohmann LG and Ulloa CU (2016). Bignoniaceae. In: iPlants prototype Checklist. Available at [www.iplants.org]. Accessed May 14, 2016.

Lohmann LG, Sfair JC, Monteiro NP and Santos Filho LAF (2013). Bignoniaceae. In: Livro vermelho da flora do Brasil (Martinelli G and Moraes MA, eds.). Andrea Jakobsson, Instituto de Pesquisas Jardim Botânico do Rio de Janeiro, Rio de Janeiro, 303-312.

Morawetz W (1982). Morphologisch-ökologische differenzierung, biologie, systematik und evolution der Neotropischen gattung Jacaranda (Bignoniaceae). Denkschriften der Österreichischen Akademie der Wissenschaften. SpringerVerlag, Wien.

Oliveira IG, Moraes AP, Almeida EM, Assis FNM, et al. (2015). Chromosomal evolution in Pleurothallidinae (Orchidaceae: Epidendroideae) with an emphasis on the genus Acianthera: chromosome number and heterochromatin. Bot. J. Linn. Soc. 178: 102-120. http://dx.doi.org/10.1111/boj.12273

Olmstead RG, Zjhra ML, Lohmann LG, Grose SO, et al. (2009). A molecular phylogeny and classification of Bignoniaceae. Am. J. Bot. 96: 1731-1743. http://dx.doi.org/10.3732/ajb.0900004

Piazzano M (1998). Números cromosómicos em Bignoniaceae de Argentina. Kurtziana 26: 179-219.

Piazzano M, Las Peñas ML, Chiarini F and Bernardello G (2015). Karyotypes and DNA content in Bignoniaceae. Caryologia 68: 175-183. http://dx.doi.org/10.1080/00087114.2015.1032606

Sampaio DS (2010). Biologia reprodutiva de espécies de Bignoniaceae ocorrentes no cerrado e variação no sistema de autoincompatibilidade. Doctoral thesis, Universidade Federal de Uberlândia, Uberlândia.

Sangalli A, Vieira MC, Scalon SPQ, Zárate NAH, et al. (2012). Morfometria de frutos e sementes e germinação de carobinha (Jacaranda decurrens subsp. symmetrifoliolata Farias \& Proença), após o armazenamento. Rev. Bras. Pl. Med. 14: 267-275. http://dx.doi.org/10.1590/S1516-05722012000200003

Silva-Castro MM, Costa CRA and Brito RF (2007). Flora da Bahia - Bignoniaceae 1: Jacaranda Jussieu. Sitientibus Sér. Ci. Biol 7: 15-31.

Spangler RE and Olmstead RG (1999). Phylogenetic analysis of Bignoniaceae based on the cpDNA gene sequences of $r b c \mathrm{~L}$ and $n d h$ F. Ann. Mo. Bot. Gard. 86: 33-46. http://dx.doi.org/10.2307/2666216

Genetics and Molecular Research 15 (4): gmr15048973 